\title{
The Description of Internal and External Factors of Fatigue at the Sidoarjo Steel Smelting Company
}

\author{
Gambaran Faktor Internal dan Faktor Eksternal Kelelahan di Perusahaan \\ Peleburan Baja Sidoarjo
}

\author{
Andy Juniar Syahfudin \\ PT Bukit Makmur Mandiri Utama \\ Jalan Pluit Selatan Raya, Pluit, Penjaringan, North Jakarta 14450, Indonesia
}

\begin{abstract}
Introduction: Work fatigue or fatigue is a kind of prevention within the body from any further physical damages. The fatigue suffered by a worker resulted in a decrease in work performance and a lack of body endurance during the work. The laborers in steel smelting companies are one of the examples of workers who potentially experience work fatigue. This research aims to ascertain both the internal and external factors of work fatigue experienced by the workers at the Sidoarjo steel smelting company. Methods: This research was conducted at the Sidoarjo steel smelting company in May 2018 with 30 workers as samples. The internal factors found in this research were the age, years of service, and nutritional status of the workers. Meanwhile, the external factors were the physical workload, work climate, and noise. This research is descriptive research with observation as the data collection method with a cross-sectional research design. The sample was calculated by applying the total population sampling technique. The data were presented descriptively in the form of frequency, percentage, and cross-tabulation among variables distributions. Result: It was revealed that the majority of the workers, as many as 17 people, suffer from mild work fatigue (56.7\%). The results of the cross-tabulation showed that moderate and severe fatigue are mostly suffered by the workers of these criteria: younger, shorter years of service, obese, fair physical workload, and work climate and noise that exceeds the Threshold Limit Value (TLV). Conclusion: It was affirmed that both the internal and external factors are related to work fatigue.
\end{abstract}

Keywords: external factors, internal factors, steel smelting, work fatigue

\section{ABSTRAK}

Pendahuluan: Kelelahan kerja merupakan bentuk perlindungan terhadap pekerja dari kerusakan yang lebih lanjut. Kelelahan yang dialami oleh pekerja berakibat kepada penurunan kemampuan kerja dan berkurangnya ketahanan tubuh selama bekerja. Pekerja peleburan baja adalah salah satu pekerja yang berpotensi mengalami kelelahan kerja. Tujuan dari penelitian ini adalah untuk mengetahui gambaran faktor internal dan eksternal tentang kelelahan kerja pada pekerja di perusahaan peleburan baja Sidoarjo. Metode: Penelitian ini dilakukan di perusahaan peleburan baja Sidoarjo pada bulan Mei 2018 dengan jumlah populasi sebanyak 30 orang.. Faktor internal dalam penelitian ini adalah umur pekerja, masa kerja dan status gizi pekerja. Sedangkan faktor eksternal adalah beban kerja fisik, iklim kerja dan kebisingan. Penelitian ini adalah penelitian deskriptif dengan metode pengumpulan data secara obervasional dan rancang bangun dalam peneltian ini adalah cross sectional. Perhitungan sampel menggunakan total populated sampling. Data disajikan secara deskriptif dalam bentuk distribusi frekuensi, presentase dan tabulasi silang antar variabel. Hasil: Sebagian besar pekerja mengalami kelelahan kerja ringan sebanyak 17 orang (56,7\%). Hasil tabulasi silang menunjukkan bahwa kelelahan kerja sedang dan tinggi lebih banyak dialami oleh pekerja dengan umur yang lebih muda, masa kerja lebih pendek, status gizi obesitas, beban kerja fisik sedang, iklim kerja dan kebisingan yang melebihi Nilai Ambang Batas (NAB). Simpulan: Penelitian ini adalah faktor internal dan faktor eksternal memiliki hubungan terhadap kejadian kelelahan kerja.

Kata kunci: faktor eksternal, faktor internal, kelelahan kerja, peleburan baja

Author for Correspondence:

Andy Juniar Syahfudin

Email: juniarandy@gmail.com

Telephone: +6281252670939

(C2019 IJOSH. Open access under CC BY NC-SA license doi: 10.20473/ijosh.v8i3.2019.336-345. Received July 07, 2018, received in revised form February 07, 2019, Accepted November 04, 2019, Published: December 2019 


\section{INTRODUCTION}

Every worker can experience work fatigue at different levels. Work fatigue or fatigue is a kind of body prevention to avoid further physical damages and can be recovered after getting a sufficient amount of rest (Tarwaka, 2015). The fatigue experienced by workers may result in a decrease in work performance and a lack of endurance of the body during the work (Suma'mur, 2014). ). In line with the ergonomics concept, the balance between workload and capacity of the workers is indispensable to attain high work performance (Tarwaka, Bakri and Sudiajeng, 2004). The National Social Security (2018) has taken note that in 2017, the number of occupational accidents reached 80,932 cases. According to the document of the International Labour Organization (2013), as many as two million workers died of occupational accidents caused by fatigue. The results were obtained from research performed to 58,115 samples, in which $32.8 \%$ or 18,828 samples suffered from fatigue (Arini and Dwiyanti, 2017). In fact, fatigue or work fatigue that is not immediately treated can be one of the factors of occupational accidents and occupational deceases (Tarwaka, 2015).

The work fatigue in many industries is caused by various factors that can be classified into two, namely internal factors and external factors. Internal factors include the age, years of service, and nutritional status of the worker. On the other hand, external factors comprise of physical workload, work climate, and noise (Tarwaka, Bakri and Sudiajeng, 2004).

One industry in which the workers are potential enough to undergo work fatigue is the steel management industry. The research authored by Paulina and Salbiah (2016) toward 31 workers at PT Kalimantan Steel discovered that as many as 29 workers $(70.9 \%)$ suffered from fatigue. There onward, it was discovered that the fatigue experienced by the workers was caused by several factors, such as age, years of service, nutritional status, hot work climate, and noise in the workplace. As a result, it was obtained that those factors have a significant correlation to the occurrence of work fatigue $(p<0.05)$ with noise as the strongest factor that influenced the fatigue.

Sidoarjo steel smelting company was a steel company that produced billets and wire coils. In this company, there were two main production processes, namely smelting and rolling. The smelting process was performed at an area known as a steel melting shop by using the basic material of scrap metal and sponge iron that are put into an iron pot. During this process, the temperature required is $1300^{\circ} \mathrm{C}-1600^{\circ} \mathrm{C}$ and applies an electric system in the form of the cathode as the smelter. The product of this process was liquid steel that later on would be relayed to the next process to be made into a billet with a width of 120-160 mm and a length of 3.9-12 m. The production at the company has a capacity of 60,000 tons/month with the production capability of approximately 24 heat $/ 24$ hours. Some of the produced billets were sold to the market, but some others were relayed to the rolling process to produce wire coils as the final product of the rolling mill section.

The numbers of the workers at the steel melting shop were 30 workers during morning shifts (07:00-15:00), 23 workers during evening shifts (15:00-23:00), and 15 workers during night shifts (23:00-07:00), with 1-hour interlude of each shift. Furthermore, the activities of the workers at the steel melting shop were diverse depending on the place they are assigned to, such as: putting the scrap metal into an iron pot; putting the scrap metal into the coil; docking the crane (sling) to the hook of the iron pot; spraying water to the outside of the hot iron pot; taking the sample of liquid steel; repairing the iron pot and the iron smelter electrode; and shaping the liquid steel.

The measurement of the physical working environment (work climate and noise) at the Sidoarjo steel smelting company in early 2018 showed critical results. It was obtained that more or less, the work climate at the steel melting shop was $>30^{\circ} \mathrm{C}$ with the noise level of about 85-110 dB(A). In other words, it can be affirmed that the measurement results indicated that the exposure of the work climate and the noise at the steel melting shop exceed the TLV that has been specified by the Minister of Manpower and Transmigration (2011).

Therefore, by referring to the results of the research conducted by Paulina and Salbiah (2016) regarding work fatigue suffered by the workers at PT Kalimantan Steel as well as the real condition of the workers and the physical working environment at Sidoarjo steel smelting company, the authors intended to analyze the occurrence of work fatigue at Sidoarjo steel smelting company. Moreover, the authors also proposed to discover the internal and external factors that caused work fatigue suffered by the workers at the Sidoarjo steel smelting company. 


\section{METHODS}

This research is observational research since there is no intervention nor special treatment given to the respondents. The research design applied in this research is the cross-sectional design. Moreover, this research is considered descriptive research without statistics tests as it merely aims to figure out the internal and external factors that are believed to cause work fatigue suffered by the workers at the Sidoarjo steel smelting company.

This research took place in the area of steel melting factory at Sidoarjo steel smelting company and was conducted during the first week of May 2018. In addition, there was no calculation to determine the sample since this research applied the total populated sampling technique.

The internal factors analyzed in this research were the age, years of service, and the workers' nutritional status. Meanwhile, the external factors covered the physical workload, hot work climate, and noise. There were two kinds of data collection in this research, namely the primary data and secondary data. The primary data was collected in different ways according to the variables.

The data of work fatigue was obtained by distributing the Industrial Fatigue Research Committee (IFRC) questionnaire that consisted of 30 questions; 10 questions on weakening activities, 10 questions on weakening motivations, and 10 questions on weakening physical states. The data regarding the age and years of service of the workers were acquired by distributing an open-question questionnaire. Furthermore, the data of the nutritional status was obtained by measuring the weight and height of the respondents which later were calculated based on the Body Mass Index (BMI) formula. The BMI was then classified into four groups as referred by the Ministry of Health of the Republic of Indonesia (2003), namely underweight, normal weight, overweight, and obese. Additionally, the data on physical workload was obtained by measuring the pulse before and during work which then calculated by applying the Cardiovascular Load (CVL) formula. Aside from that, the data on work climate was gathered through measurement by using Heat Stress Apparatus equipment, while the data on noise was acquired though measurement by using Sound level Meter equipment. Likewise, the secondary data of this research was in the form of a company profile as well as the measurement of the physical working environment at the Sidoarjo steel smelting company.

\section{RESULTS}

\section{General Description of Sidoarjo Steel Smelting Company}

Sidoarjo steel smelting company is a Foreignowned Company and one of the members of the Lakshmi Mittal (LNM) Group. The products of this company are in the form of billets and wire coals. The total production reached a number of 700,000 tons with $70 \%$ products for domestic markets and $30 \%$ are exported to other countries. This fact placed the company as the second-biggest steel company after PT Krakatau Steel (Enterprise) Tbk.

Overall, the products of the Sidoarjo steel smelting company is manufactured by utilizing modern facilities, starting from the steelmaking through slag-free electric furnaces, secondary melting, continuous casting for clean steel results, until the automatic rolling process. The results of the production are highly monitored with quality control and tested at every stage.

\section{The Internal Factors of the Workers}

The internal factors in this research are limited to 3 variables, namely the age, years of service, and the nutritional status of the workers. The results of the research are presented in Table 1, Table 2, and Table 3. Table 1 depicted that the age group of 3540 years old is the group with the most workers, as many as 9 workers (30\%). The group of the most years of service as shown in Table 2, which is the group with $>21$ years of service, as many as 13 workers $(43.3 \%)$. The most nutritional status of the workers, namely normal nutritional status, is presented in Table 3, which consists of 27 workers $(90 \%)$.

\section{The External Factors of the Workers}

The external factors of the workers in this research consist of 3 variables, such as physical workload, work climate, and noise. The workload in this research is measured by Cardiovascular Load (CVL) which compared the increase of working pulse to the maximum pulse. There onward, the workload is distributed into 5 groups, namely mild, moderate, rather heavy, heavy, and very heavy. 
The measurements of work climate and noise in this research are completed at five points from 09:0013:00 UTC+7. The measurement points are adjusted based on the place where the respondents work. The results of the work climate measurement consist of wet-bulb temperature (Tw), dry-bulb temperature (Td), globe thermometer temperature (Tg), WetBulb Globe Temperature Index (WGBT), relative humidity $(\mathrm{RH})$, and airflow velocity. Meanwhile, the results of noise measurements are in the form of results and range. The frequency distribution of the results of work climate and noise measurements are then presented. The results of the measurements and the frequency distribution of the workers' external

Table 1. The Age Distribution of the Workers at Sidoarjo Steel Smelting Company in 2018

\begin{tabular}{ccc}
\hline Age (Years old) & Frequency (n) & Percentage (\%) \\
\hline $29-34$ & 8 & 26.7 \\
$35-40$ & 9 & 30.0 \\
$41-46$ & 4 & 13.3 \\
$47-52$ & 2 & 6.7 \\
$53-58$ & 7 & 23.3 \\
\hline Total & 30 & 100 \\
\hline
\end{tabular}

Table 2. The Years of Service Distribution of the Workers at Sidoarjo Steel Smelting Company in 2018

\begin{tabular}{ccc}
\hline $\begin{array}{c}\text { Years of Service } \\
\text { (Years) }\end{array}$ & Frequency (n) & Percentage (\%) \\
\hline$\leq 5$ & 5 & 16.7 \\
$6-10$ & 4 & 13.3 \\
$11-15$ & 7 & 23.3 \\
$16-20$ & 1 & 3.3 \\
$\geq 21$ & 13 & 43.3 \\
\hline Total & 30 & 100 \\
\hline
\end{tabular}

Table 3. The Distribution of Nutritional Status at Sidoarjo Steel Smelting Company in 2018

\begin{tabular}{ccc}
\hline Nutritional Status & Frequency (n) & Percentage (\%) \\
\hline Underweight & 0 & 0 \\
Normal weight & 27 & 90 \\
Overweight & 0 & 0 \\
Obese & 3 & 10 \\
\hline Total & 30 & 100 \\
\hline
\end{tabular}

factors are comprehended in Table 4, Table 5, Table 6, Table 7, Table 8, and Table 9.

\section{Workload}

Referring to Table 4, it can be seen that in average, the resting pulse of the workers at Sidoarjo steel smelting company is 92 beats/minute, while the average working pulse is 115 beats/minute, followed by the average of the CVL level of the workers as much as $27 \%$. Thus, it can be asserted that typically, the workers received a mild physical workload.

Table 4. The Results of Physical Workload Measurement at Sidoarjo Steel Smelting Company in 2018

\begin{tabular}{|c|c|c|c|c|}
\hline Respondent & $\begin{array}{l}\text { Resting } \\
\text { Pulse }\end{array}$ & $\begin{array}{c}\text { Working } \\
\text { Pulse }\end{array}$ & CVL & Status \\
\hline 1 & 74 & 96 & 20 & Mild \\
\hline 2 & 114 & 140 & 37 & Moderate \\
\hline 3 & 90 & 115 & 27 & Mild \\
\hline 4 & 128 & 147 & 35 & Moderate \\
\hline 5 & 84 & 109 & 31 & Moderate \\
\hline 6 & 84 & 112 & 27 & Mild \\
\hline 7 & 90 & 115 & 26 & Mild \\
\hline 8 & 81 & 102 & 25 & Mild \\
\hline 9 & 108 & 140 & 40 & Moderate \\
\hline 10 & 90 & 131 & 45 & Moderate \\
\hline 11 & 132 & 145 & 27 & Mild \\
\hline 12 & 102 & 117 & 19 & Mild \\
\hline 13 & 90 & 104 & 15 & Mild \\
\hline 14 & 60 & 88 & 24 & Mild \\
\hline 15 & 93 & 127 & 45 & Moderate \\
\hline 16 & 84 & 104 & 25 & Mild \\
\hline 17 & 82 & 98 & 15 & Mild \\
\hline 18 & 94 & 109 & 20 & Mild \\
\hline 19 & 87 & 118 & 30 & Mild \\
\hline 20 & 102 & 123 & 33 & Moderate \\
\hline 21 & 84 & 102 & 22 & Mild \\
\hline 22 & 72 & 95 & 22 & Mild \\
\hline 23 & 88 & 102 & 15 & Mild \\
\hline 24 & 92 & 118 & 30 & Mild \\
\hline 25 & 104 & 128 & 29 & Mild \\
\hline 26 & 97 & 120 & 28 & Mild \\
\hline 27 & 87 & 130 & 46 & Moderate \\
\hline 28 & 90 & 112 & 22 & Mild \\
\hline 29 & 88 & 103 & 19 & Mild \\
\hline 30 & 87 & 105 & 23 & Mild \\
\hline Average & 92 & 115 & 27 & Mild \\
\hline
\end{tabular}


Table 5. The Distribution of Physical Workload at Sidoarjo Steel Smelting Company in 2018

\begin{tabular}{ccc}
\hline $\begin{array}{c}\text { Physical } \\
\text { Workload }\end{array}$ & Frequency (n) & Percentage (\%) \\
\hline Mild & 22 & 73.3 \\
Fair & 8 & 26.7 \\
\hline Total & 30 & 100 \\
\hline
\end{tabular}

Table 6. The Results of Work Climate Measurement at Sidoarjo Steel Smelting Company in 2018

\begin{tabular}{|c|c|c|c|c|c|}
\hline Location & $\begin{array}{l}\text { Tw } \\
\left({ }^{\circ} \mathbf{C}\right)\end{array}$ & $\operatorname{Td}\left({ }^{\circ} \mathrm{C}\right)$ & $\operatorname{Tg}\left({ }^{\circ} \mathrm{C}\right)$ & $\begin{array}{c}\text { WGBT } \\
\left({ }^{\circ} \mathrm{C}\right)\end{array}$ & $\begin{array}{l}\text { RH } \\
(\%)\end{array}$ \\
\hline Point 1 & 27.7 & 37.1 & 43.1 & 32.3 & 45 \\
\hline Point 2 & 26.0 & 34.2 & 39.2 & 30.3 & 49 \\
\hline Point 3 & 26.8 & 33.6 & 38.6 & 32.1 & 50 \\
\hline Point 4 & 27.8 & 33.8 & 42.8 & 32.7 & 57 \\
\hline Point 5 & 27.5 & 37.7 & 40.6 & 31.8 & 50 \\
\hline Average & 27.2 & 35.3 & 40.9 & 31.9 & 50.2 \\
\hline \multicolumn{2}{|c|}{ Airflow velocity } & & & \multicolumn{2}{|c|}{$0.2-3(\mathrm{~m} / \mathrm{dt})$} \\
\hline
\end{tabular}

A similar thing can also be remarked in Table 5 , the table of the distribution of the physical workload of the workers at the Sidoarjo steel smelting company. The table showed that a mild physical workload is the most workload received by the workers with a total number of 22 workers (73.3\%).

\section{Work Climate}

Denoting to Table 6, it can be concluded that the average of wet-bulb temperature (Tw) in the area of Sidoarjo steel smelting company is $27.2^{\circ} \mathrm{C}$, while the average of dry-bulb temperature (Td) is $35.3^{\circ} \mathrm{C}$, and the average of globe thermometer temperature ( $\mathrm{Tg}$ ) is $40.9^{\circ} \mathrm{C}$. Besides, the relative humidity (RH) has an average of $50.2 \%$. Moreover, the WGBT in the area of the Sidoarjo steel smelting company is $31.9^{\circ} \mathrm{C}$. Furthermore, it is to be noted that the WGBT is the index that shows the level of the work climate in a certain place.

From Table 6, it can also be perceived that the highest wet-bulb temperature (Tw) is at point 4 , as much as $27.8^{\circ} \mathrm{C}$. The highest dry-bulb temperature (Td) is discovered at point 5 , as much as $37.7^{\circ} \mathrm{C}$, while the highest globe thermometer temperature (Tg) is at point 1 , as much as $43.1^{\circ} \mathrm{C}$. As for the
Table 7. The Distribution of Work Climate at Sidoarjo Steel Smelting Company in 2018

\begin{tabular}{ccc}
\hline $\begin{array}{c}\text { Work Climate } \\
\text { Exposure }\end{array}$ & Frequency (n) & Percentage (\%) \\
\hline $\begin{array}{c}\text { Does not exceed } \\
\text { the TLV }\end{array}$ & 14 & 46.7 \\
Exceeds the TLV & 16 & 53.3 \\
\hline Total & 30 & 100 \\
\hline
\end{tabular}

Table 8. The Results of Noise Measurement at Sidoarjo Steel Smelting Company in 2018

\begin{tabular}{ccc}
\hline Location & Result $(\mathbf{d b A})$ & Range $(\mathbf{d b A})$ \\
\hline Point 1 & 110 & $95-110$ \\
Point 2 & 80.18 & $70-85$ \\
Point 3 & 104.5 & $99-110$ \\
Point 4 & 105 & $110-115$ \\
Point 5 & 97.5 & $95-100$ \\
\hline Average & & 99.4 \\
\hline
\end{tabular}

relative humidity $(\mathrm{RH})$, it is found that the highest humidity is at point 4 , which is $57 \%$, while the highest WGBT is at point 3 , as much as $32.7^{\circ} \mathrm{C}$.

The distribution of the workers exposed to the hot work climate that exceeds the TLV can be seen in Table 7. From Table 7, it can be remarked that as many as 16 workers $(53.3 \%)$ are exposed to a humid work climate that exceeds the TLV. The TLV of work climate and the WGBT have been determined (Minister of Manpower and Transmigration, 2011).

Noise

By denoting Table 8, it is known that four out of five points had noise that exceeds the TLV, for instance; point 1 as high as $110 \mathrm{~dB}(\mathrm{~A})$, point 3 as high as $104.5 \mathrm{~dB}(\mathrm{~A})$, point 4 as high as $105 \mathrm{~dB}(\mathrm{~A})$, and point 5 as high as $97.5 \mathrm{~dB}(\mathrm{~A})$. The highest noise value is discovered at point 1 with a value of 110 $\mathrm{dB}(\mathrm{A})$. Additionally, the average noise value in the area of steel melting shop is $99.4 \mathrm{~dB}(\mathrm{~A})$, which can also be exclaimed exceeding the determined TLV.

The distribution of the workers exposed to the noise of $>85 \mathrm{~dB}(\mathrm{~A})$ can be seen in Table 9 . From the table, it is affirmed that most of the workers who are as many as 16 workers $(53.3 \%)$ are exposed to the noise of $>85 \mathrm{~dB}(\mathrm{~A})$ during working hours. 


\section{Work Fatigue}

The measurement of work fatigue in this research is based on the Industrial Fatigue Research Committee (IFRC) questionnaires, which consisted of 30 questions. From the research, it is obtained that the lowest individual score is 0 , while the highest is 90. The work fatigue categories in the questionnaire comprise mild, moderate, less severe, and very severe. The measurement of work fatigue in the area of steel melting shop can be seen in Table 10. From Table 10, it can be alleged that the majority of the workers in the area of steel melting shop suffer from mild fatigue, which is as many as 17 workers $(56.7 \%)$.

\section{Cross Tabulation between the Internal Factors of the Workers and Work Fatigue}

Table 11 shows that the workers with the age of $>39.5$ years old are those who experience mild fatigue the most, which is as many as 10 workers $(66.7 \%)$. In the meantime, the majority of the workers whose ages are $<39.5$ years old suffer from moderate work fatigue, which is as many as 7 workers $(46.7 \%)$ and severe work fatigue that is experienced by 1 person (6.6\%). From the results, it can be perceived that the workers whose ages are $<39.5$ years old tend to undergo moderate and severe fatigue compared to those whose ages are $>39.5$ years old. In other words, it can be stated that

Table 9. The Distribution of Noise at Sidoarjo Steel Smelting Company in 2018

\begin{tabular}{ccc}
\hline $\begin{array}{c}\text { Noise Exposure } \\
(\mathbf{d b A})\end{array}$ & Frequency (n) & Percentage (\%) \\
\hline$\leq 85$ & 14 & 46.7 \\
$>85$ & 16 & 53.3 \\
\hline Total & 30 & 100 \\
\hline
\end{tabular}

Table 10.The Distribution of Work Fatigue at Sidoarjo Steel Smelting Company in 2018

\begin{tabular}{ccc}
\hline Work Fatigue & Frequency (n) & Percentage (\%) \\
\hline Mild & 17 & 56.7 \\
Moderate & 12 & 40 \\
Less Severe & 1 & 3.3 \\
Very Severe & 0 & 0 \\
\hline Total & 30 & 100 \\
\hline
\end{tabular}

the younger the worker, the higher the chance of the worker to experience a higher fatigue level.

Table 12 portrays the result of cross-tabulation between the independent variable, namely years of service, and the dependent variable, for instance, the work fatigue. In results, Table 12 displayed that the workers who had been working for $>15$ years tend to experience mild fatigue, which was as many as 9 people $(64.3 \%)$. Additionally, the workers whose years of service are $<15$ years tend to suffer from moderate fatigue, which is as many as 7 people $(43.75 \%)$ and severe fatigue with the number of 1 person $(6.25 \%)$. From the results described beforehand, it can be specified that the workers whose years of service are $<15$ years tend to experience moderate and severe fatigue compared to those whose years of service are $>15$ years. Therefore, it can be affirmed that the shorter the years of service, the higher the level of fatigue experienced by the workers.

Table 13 presents that the workers with normal nutritional status suffer from a mild work fatigue, which is as many as 17 workers $(63 \%)$, while the workers whose nutritional status is considered obese faced moderate and severe fatigue, that are as many as 2 workers (66.7\%) and 1 worker (33.3\%), respectively. From the results, the workers with obesity in their nutritional status tend to experience moderate and severe fatigue, compared to those

Table 11.Cross Tabulation between Work Fatigue and the Age of the Workers at Sidoarjo Steel Smelting Company in 2018

\begin{tabular}{ccccccc}
\hline \multirow{2}{*}{$\begin{array}{c}\text { Age } \\
\text { Years }\end{array}$} & \multicolumn{5}{c}{ Work Fatigue } \\
\cline { 2 - 7 } old) & \multicolumn{2}{c}{ Mild } & \multicolumn{2}{c}{ Moderate } & \multicolumn{2}{c}{ Severe } \\
\cline { 2 - 7 } & $\mathbf{n}$ & $\%$ & n & $\%$ & n & $\%$ \\
\hline$\leq 39.5$ & 7 & 46.7 & 7 & 46.7 & 1 & 6.6 \\
$>39.5$ & 10 & 66.7 & 5 & 33.3 & 0 & 0 \\
\hline
\end{tabular}

Table 12.Cross Tabulation between Work Fatigue and Years of Service at Sidoarjo Steel Smelting Company in 2018

\begin{tabular}{ccccccc}
\hline Years of & \multicolumn{5}{c}{ Work Fatigue } \\
\cline { 2 - 7 } $\begin{array}{c}\text { Service } \\
\text { (Year) }\end{array}$ & \multicolumn{2}{c}{ Mild } & \multicolumn{2}{c}{ Moderate } & \multicolumn{2}{c}{ Severe } \\
\cline { 2 - 7 } & $\mathbf{n}$ & $\mathbf{\%}$ & $\mathbf{n}$ & $\mathbf{\%}$ & $\mathbf{n}$ & $\%$ \\
\hline$\leq 15$ & 8 & 50 & 7 & 43.75 & 1 & 6.25 \\
$>15$ & 9 & 64.3 & 5 & 35.7 & 0 & 0 \\
\hline
\end{tabular}


Table 13. Cross Tabulation between Work Fatigue and Nutritional Status at Sidoarjo Steel Smelting Company in 2018

\begin{tabular}{|c|c|c|c|c|c|c|}
\hline \multirow{3}{*}{$\begin{array}{c}\text { Nutritional } \\
\text { Status }\end{array}$} & \multicolumn{6}{|c|}{ Work Fatigue } \\
\hline & \multicolumn{2}{|c|}{ Mild } & \multicolumn{2}{|c|}{ Moderate } & \multicolumn{2}{|c|}{ Severe } \\
\hline & $\mathbf{n}$ & $\%$ & n & $\%$ & n & $\%$ \\
\hline $\begin{array}{l}\text { Normal } \\
\text { weight }\end{array}$ & 17 & 63 & 10 & 37 & 0 & 0 \\
\hline Obese & 0 & 0 & 2 & 66.7 & 1 & 33.3 \\
\hline
\end{tabular}

Table 14. Cross Tabulation between Work Fatigue and Physical Workload at Sidoarjo Steel Smelting Company in 2018

\begin{tabular}{ccccccc}
\hline \multirow{2}{*}{ Workload } & \multicolumn{6}{c}{ Work Fatigue } \\
\cline { 2 - 7 } & \multicolumn{2}{c}{ Mild } & \multicolumn{2}{c}{ Moderate } & \multicolumn{2}{c}{ Severe } \\
\cline { 2 - 7 } & $\mathbf{n}$ & $\mathbf{\%}$ & $\mathbf{n}$ & $\mathbf{\%}$ & $\mathbf{n}$ & $\%$ \\
\hline Mild & 17 & 73.9 & 6 & 26.1 & 0 & 0 \\
Fair & 0 & 0 & 6 & 85.7 & 1 & 14.3 \\
\hline
\end{tabular}

whose nutritional status is normal. Accordingly, it can be asserted that the worse the nutritional status of a worker, the more severe the fatigue she/he might undergo.

\section{Cross Tabulation between the External Factors of the Workers and Work Fatigue}

Table 14 displays that most of the workers with a mild physical workload, as many as 17 workers (73.9\%), suffer from mild fatigue. Furthermore, the majority of the workers with fair physical workload tend to experience moderate fatigue, which is as many as 6 workers $(85.7 \%)$ and severe fatigue, which consisted of 1 worker (14.3\%). From the results, it can be proclaimed that the workers with fair physical workload tend to undergo moderate and severe fatigue if compared to those with a fair physical workload. In other words, it can also be stated that the more physical workload received by the workers, the higher the level of fatigue they experience.

Table 15 indicates that all of the workers exposed to a humid work climate which did not exceed the TLV, as many as 14 workers (14\%), experienced mild fatigue. Meanwhile, the workers who are exposed to a humid work climate which exceeds the TLV mostly suffer from moderate fatigue (12 workers or $75 \%$ ) and severe fatigue (1 worker or $6.25 \%$ ). Hence, from the results described in advance, it can be proclaimed that the workers
Table 15. Cross Tabulation between Work Fatigue and Work Climate at Sidoarjo Steel Smelting Company in 2018

\begin{tabular}{|c|c|c|c|c|c|c|}
\hline \multirow{3}{*}{$\begin{array}{c}\text { Work } \\
\text { Climate }\end{array}$} & \multicolumn{6}{|c|}{ Work Fatigue } \\
\hline & \multicolumn{2}{|c|}{ Mild } & \multicolumn{2}{|c|}{ Moderate } & \multicolumn{2}{|c|}{ Severe } \\
\hline & n & $\%$ & $\mathrm{n}$ & $\%$ & n & $\%$ \\
\hline $\begin{array}{c}\text { Does not } \\
\text { exceed the } \\
\text { TLV }\end{array}$ & 14 & 100 & 0 & 0 & 0 & 0 \\
\hline $\begin{array}{l}\text { Exceeds } \\
\text { the TLV }\end{array}$ & 3 & 18.75 & 12 & 75 & 1 & 6.25 \\
\hline
\end{tabular}

Table 16. Cross Tabulation between Work Fatigue and Noise at Sidoarjo Steel Smelting Company in 2018

\begin{tabular}{ccccccc}
\hline \multirow{2}{*}{ Noise } & \multicolumn{6}{c}{ Work Fatigue } \\
\cline { 2 - 7 } & \multicolumn{2}{c}{ Mild } & \multicolumn{2}{c}{ Moderate } & \multicolumn{2}{c}{ Severe } \\
\cline { 2 - 7 } & $\mathbf{n}$ & $\mathbf{0}$ & $\mathbf{n}$ & $\mathbf{\%}$ & $\mathbf{n}$ & $\mathbf{\%}$ \\
\hline$\leq 85$ & 14 & 100 & 0 & 0 & 0 & 0 \\
$>85$ & 3 & 18.8 & 12 & 75 & 1 & 6.3 \\
\hline
\end{tabular}

who are exposed to a humid-work climate that exceeds the TLV tend to experience moderate and severe fatigue, compared to those who are exposed to a humid-work climate that does not exceed the TLV. In other words, it is affirmable that the hotter the work climate exposed to the workers, the more severe the fatigue experienced by the workers.

Table 16 discloses that the entire workers who are exposed to noise that did not exceed the TLV, as many as 14 workers $(100 \%)$ suffer from mild fatigue. Whereas, most of the workers exposed to noise that exceeds the TLV suffer from moderate fatigue, which is as many as 12 workers $(75 \%)$ and severe fatigue, which consisted of 1 worker $(6.3 \%)$. Consequently, from the results, it can be identified that the workers who are exposed to noise that exceeds the TLV tend to experience moderate and severe fatigue, compared to the workers exposed to noise that did not exceed the TLV.

\section{DISCUSSION}

\section{The Internal Factors of the Workers}

Age is one of the internal factors of the workers that cannot be manipulated (Anindya, 2017). The results of the research indicate that the age group with most members at the Sidoarjo steel smelting 
company is the group of 35-40 years old, which consists of 9 people (30\%). The workers whose ages are $<39.5$ years old mostly suffer from moderate and severe fatigue compared to the workers whose ages are $>39.5$ years old.

According to the observation on the younger workers, it was obtained that generally, they received more physical workload than the older workers. Likewise, the younger workers were found more in the area with work climate and noise that exceeds the TLV. In this research, the fair workload and work climate, as well as noise that exceeds the TLV, is believed to cause more severe work fatigue.

From the analysis that had been done, it can be concluded that the younger the age of the workers, the more severe the level of work fatigue. Apparently, this result is in line with the result of the research conducted by Anindya (2017). Her research regarding work fatigue of the container crane operators at PT Terminal Petikemas Surabaya came up with the results that the workers whose ages are $<41$ years old experience more of moderate fatigue $(80 \%)$ compared to the workers whose ages are $>41$ years old. Aside from that, Lusiana, Zahroh and Baju (2014) also explained that workers with a younger age tend to struggle more in recovery and are easier to suffer from fatigue compared to older workers. Ostensibly, because older workers are believed to have better emotional stability.

On the contrary, the result of this research is different from the prior research authored by Paulina and Salbiah (2016). Their research claims that there is a strong correlation between the age of the workers as a variable and work fatigue at PT Kalimantan Steel $(\mathrm{p}<0.05)$. Furthermore, it is explained that as the age increases, the volume of lungs, eyesight, the speed of distinguishing something, hearing, and decision-making ability decrease (Paulina and Salbiah, 2016). Moreover, they added that these problems are caused by the degeneration of the organs which resulted in a decrease in work performance (Paulina and Salbiah, 2016).

Years of service is the second internal factor that causes work fatigue. The results of the research indicated that the group with the most workers is the group of $>21$ years of service, which consisted of 13 workers (43.3\%). Additionally, moderate and severe work fatigue is mostly experienced by the workers whose years of service $<15$ years, compared to the workers with $>15$ years of service.
Bestowing to the analysis on the workers with shorter years of service, it is obtained that those workers are mostly work in the area with humid work climate and noise that exceeds the TLV. Interestingly, in this research, the exposure of work climate and noise that exceeds the TLV is discovered to cause more moderate and severe fatigue.

From the analysis above, it can be determined that the shorter the years of service, the more severe the work fatigue experienced by the workers. Remarkably, this result is akin to the result of the research piloted by Anindya (2017). Her research at PT Terminal Petikemas Surabaya discovered that the workers with $<10$ years of service tend to suffer moderate fatigue, compared to the workers with $>10$ years of service. Generally, workers with more years of service had adapted better to the working environment. Consequently, this makes the workers with more years of service not undergo work fatigue (Lusiana, Zahroh and Baju, 2014).

Nonetheless, Paulina and Salbiah (2016) proposed another statement regarding this fact. In their research completed on the workers at PT Kalimantan Steel, they came up with the result that the workers with more years of service tend to experience moderate and severe fatigue, which is as many as 16 workers $(72.7 \%)$. In fact, this result is in line with what Grandjean (1993) long years of service has the potential for severe fatigue as the result of a long accumulation of fatigue during those periods.

The third internal factor that causes work fatigue is the nutritional status of the workers. The determination of nutritional status involved two important aspects, namely height, and weight. The result of this research pointed out that almost all of the workers have normal nutritional status, which is as many as 27 workers $(90 \%)$, while the other 3 had obesity. In addition, moderate and severe work fatigue are discovered to be experienced by the workers whose nutritional status is obese. The result of the cross-tabulation shows that 2 out of 3 workers with obesity suffer from moderate fatigue, whilst the other 1 suffer from severe fatigue.

Comprehensively, from the previous analysis, it can be acknowledged that the worse the nutritional status, the more severe the fatigue. Moreover, this result was alike to the result of the which discloses that there is a significant correlation between the nutritional status of the workers and work fatigue at PT Kalimantan Steel. Aside from that, Suma'mur (2014) added that both underweight and overweight 
may result in occupational diseases and the decrease in work performance.

In contrast, Handayani, Suhartono and Nurjazuli (2015) avowed that the worse the nutritional status of the workers (overweight and obese), the rarer the work fatigue. Likewise, Handayani, Suhartono and Nurjazuli (2015) enhanced that such thing since the overweight workers have more tissues that function as good isolators than normal or underweight workers, who only have $1 / 3$ of the isolator.

\section{The External Factors of the Workers}

From an ergonomics point of view, every worker deemed to have her/his physical workload. The level of workload received by a worker depended on the balance between the capacity of the worker and the given demand (Tarwaka, 2014). The research completed at the Sidoarjo steel smelting company indicates that the majority of the workers receive mild workload, which was as many as 23 people $(76.7 \%)$. In addition, moderate and severe fatigue is experienced more by the workers with a fair workload rather than by those with a mild workload.

Thus, from the analysis, it is certain that the fairer the physical workload, the more severe the fatigue. Furthermore, the result of this research is the same as the research conducted by Handayani, Suhartono and Nurjazuli (2015), which affirmed that there is a significant correlation between physical workload and work fatigue. Above and beyond, Tarwaka, Bakri and Sudiajeng (2004) declared that the fairer the workload, the more energy is needed. Consequently, if the energy released is too excessive, the workers would suffer from fatigue more quickly.

However, Lusiana, Zahroh and Baju (2014) came up with a different idea; she did not discover any significant correlation between physical workload as a variable and work fatigue in furniture workers. Furthermore, she continued that the results are due to the time management applies at the company, which is $75 \%$ for work and $25 \%$ for rest.

There are two factors of the physical working environment in this research, namely hot work climate and noise. The factor of the physical working environment can be an additional workload for the workers at the Sidoarjo steel smelting company. From the measurement of the work climate in the area of steel smelting company, it is obtained that the average WGBT is $31.9^{\circ} \mathrm{C}$. The temperature generally can exceed TLV depending on the physical workload and time management (Ministry of Manpower and Transmigration, 2011). Furthermore, the majority of the workers in the area of steel smelting company are exposed to a work climate that exceeds the TLV, which is as many as 16 people $(53.3 \%)$. Consequently, those workers mostly experience moderate and severe fatigue compared to the workers who are exposed to a work climate that did not exceed the TLV.

Accordingly, from the analysis, it is confirmed that the higher the exposure of hot work climate to the workers, the more severe the fatigue the workers experienced. The inference of this analysis is in line with the research authored by Paulina and Salbiah (2016), which declared that there is a significant correlation between work climate as a variable and work fatigue. Moreover, Paulina and Salbiah (2016) added that the workers exposed to the temperature of $>30^{\circ} \mathrm{C}$ tend to suffer from moderate and severe fatigue $(81.8 \%)$.

Additionally, Lusiana, Zahroh and Baju (2014) in her research claimed that the water content in the body will decrease if a worker stays for a long time in the area with hot pressure. As a result, it possibly affects the body endurance of the workers. Subsequently, untreated work fatigue may lead to other occupational diseases, such as heat cramps, heat stress, heat exhaustion, heatstroke, and miliaria (Suma'mur, 2014).

Besides the extreme work climate, it is detected that the Sidoarjo steel smelting company also has extreme noise. Based on the research completed in five different points, it is perceived that the average noise value in the area of Sidoarjo steel smelting company is $99.4 \mathrm{~dB}(\mathrm{~A})$. This value indicated that generally, the noise in the company exceeds the TLV. Furthermore, as many as 16 workers $(53.3 \%)$ are known exposed to the noise that exceeds the TLV. In results, the workers who are continuously exposed to the exceeds noise experienced moderate and severe work fatigue, compared to the workers who are not exposed to the exceeds noise.

Hence, from the analysis above, it is disclosed that the higher the noise exposure to the workers, the more severe the fatigue. As a supportive statement, Paulina and Salbiah (2016) claimed that there was a significant correlation between noise as a variable and work fatigue; the workers who are exposed to the noise of $>85 \mathrm{~dB}(\mathrm{~A})$ tend to suffer from moderate and severe fatigue.

It has been determined that the TLV of noise in a workplace is $86 \mathrm{~dB}(\mathrm{~A})$ during maximum 8 
working hours per day and 5 working days per week or 40 working hours per week (Ministry of Manpower and Transmigration, 2011). Moreover, it is common that the noise in the industry is caused by the production equipment (Paulina and Salbiah, 2016). However, noise may cause communication disruption and fatigue that could decrease work performances (Suma'mur, 2014).

\section{Work Fatigue}

The research that had been carried out at the Sidoarjo steel smelting company specified that work fatigue is experienced by all of the workers. From the results, it is distinguished that more than half of the workers, as many as 17 workers $(56.7 \%)$, undergo mild fatigue. Referring to Tarwaka (2015), mild fatigue is a safe condition in which recovery was not yet necessary. Other than that, the workers also suffer from moderate fatigue $(40 \%)$ and severe fatigue $(3.3 \%)$. These conditions, especially severe fatigue, as Suma'mur (2014) explained, are the conditions that need to be taken care of as soon as possible to prevent detrimental effects on the workers.

\section{CONCLUSION}

The correlation between the internal factors and work fatigue portrayed that the higher severity level of fatigue tends to be experienced by the workers with younger age, lesser years of service, and worse nutritional status. In addition, the correlation between the external factors and work fatigue depicted that the workers who were exposed to heavier physical workload and more exposure on hot work climate and noise tend to suffer from a higher severity level of fatigue.

\section{ACKNOWLEDGMENT}

The correlation between the internal factors and work fatigue portrayed that the higher severity level of fatigue tends to be experienced by the workers with younger age, lesser years of service, and worse nutritional status. In addition, the correlation between the external factors and work fatigue depicted that the workers who were exposed to heavier physical workload and more exposure on hot work climate and noise tend to suffer from a higher severity level of fatigue.

\section{REFERENCES}

Anindya, N. Y. (2017) Kelelahan Kerja pada Operator Container Crane di PT. Terminal Petikemas Surabaya dan Faktor Determinannya. Undergraduate Thesis. Surabaya: Faculty of Public Health, Universitas Airlangga.

Arini, S. Y. and Dwiyanti, E. (2017) 'Analisis Faktor yang Berhubungan dengan terjadinya Kelelahan Kerja pada Pengumpul Tol di Perusahaan Pengembang Jalan Tol Surabaya', The Indonesian Journal of Occupational Safety and Health, 4(2), pp. 113-122.

Grandjean, E. (1993) Fitting the Task to the Man: An Ergonomic Approach. 4th edn. London: Taylor \& Francis Ltd.

Handayani, S., Suhartono and Nurjazuli (2015)

'Faktor-Faktor yang Berhubungan Dengan Waktu Reaksi Rangsang Cahaya pada Tenaga Kerja yang Terpapar Panas di PT. Baja Kurnia Ceper Klaten', Jurnal Kesehatan Lingkungan Indonesia, 4(1), pp. 27-32.

International Labour Organization (2013) Keselamatan dan Kesehatan Kerja : Sarana untuk Produktivitas. 5th edn. Jakarta: International Labour Organization.

Lusiana, D., Zahroh, S. and Baju, S. (2014) 'Penyebab Kelelahan Kerja pada Pekerja Mebel', Kesmas Jurnal Kesehatan Masyarakat Nasional, 8(8), pp. 386-392.

Ministry of Manpower and Transmigration (2011)

Regulation Number 13 of 2011 on Threshold Limit Value of Physical Factors and Chemical Factors in a Workplace. Jakarta: Ministry of Manpower and Transmigration.

National Social Security (2018) Data Kecelakaan Kerja Tahun 2017, Jakarta: National Social Security of the Republic of Indonesia.

Paulina and Salbiah (2016) 'Faktor-Faktor yang Berhubungan dengan Kelelahan Pekerja di PT Kalimantan Steel', Vokasi Kesehatan, 2(2), pp. 165-172.

Suma'mur, P. K. (2014) Higiene Perusahaan dan Kesehatan Kerja (HIPERKES). 2nd edn. Jakarta: Sagung Seto.

Tarwaka (2015) Ergonomi Industri: Dasar-Dasar Pengetahuan Ergonomi dan Aplikasi di Tempat Kerja. Surakarta: Harapan Press.

Tarwaka, Bakri, S. and Sudiajeng, L. (2004) Ergonomi untuk Keselamatan, Kesehatan Kerja dan Produktivitas. Surakarta: Uniba Press. 